\title{
Emerging Scholar Best Article Award, 2019
}

\author{
Roger J. R. Levesque ${ }^{1}$
}

Published online: 4 November 2019

(c) Springer Science+Business Media, LLC, part of Springer Nature 2019
The editors of the Journal of Youth and Adolescence are very pleased to announce the 2019 recipient of its Emerging Scholar Best Article Award. This award goes to the article's lead author, who must be an "emerging scholar" (i.e., an untenured researcher, such as a graduate student, postdoctoral scholar, research scientist, or assistant professor) at the time their manuscript was accepted. The recipient of the award is selected by editorial board members who evaluate volume's manuscripts on the basis of their innovative and substantive contributions to the empirical understanding of adolescence. In addition to receiving the recognition from colleagues, the winner receives a financial award generously provided by Springer, the journal's publisher.

The 2019 winner is Adam A. Rogers, for his article entitled “Adolescents' daily romantic experiences and negative mood: A dyadic, intensive longitudinal study" (Rogers et al. 2018). Dr. Rogers is an assistant professor at Brigham Young University, in its School of Family Life. His research focuses on family dynamics that contribute to adolescents' development of competence and psychopathology, with a particular lens toward gender socialization. His co-authors were all from Arizona State University. They included Thao Ha, who is an Assistant Professor in the Department of Psychology at Arizona State University, Kimberly A. Updegraff, who is a Cowden Distinguished Professor of in the T. Denny Sanford School of Social and Family Dynamics at Arizona State University, and Masumi Iida, who is an Assistant Professor in the T. Denny Sanford Schoolof Social and Family Dynamics at Arizona State University.

Dr. Rogers' study examined how adolescents' romantic relationships present unique developmental challenges that can portend psychological difficulties. He was particularly interested in the degree to which daily romantic transactions

Roger J. R. Levesque

rlevesqu@indiana.edu

Indiana University, 302 Sycamore Hall, Bloomington, IN, USA potentiate fluctuations in negative mood. The study examined associations between adolescents' daily romantic relationship experiences and their same-day negative affective states. Using a dyadic ecological momentary assessment (EMA) design, he and his colleagues followed an ethnically and socioeconomically diverse sample of 98 adolescent romantic couples twice weekly for 12 weeks. Their study indicated that various daily romantic experiences (e.g., conflict, feelings about the relationship) predicted greater same-day negative affect. Importantly, they also found that, beyond the effects of these romantic experiences, adolescent couples were synchronized in their fluctuating negative affective states, which evidenced emotional contagion. Their findings begin to pinpoint how romantic relationships influence adolescents' everyday lives and emotional development.

The journal's editors view receiving the award as a considerably distinctive accomplishment. The journal publishes 12 issues per year, each typically containing about 16 manuscripts. In addition, it is notable that, every year, fewer and fewer first authors are emerging scholars. Although fewer emerging scholars qualify to be considered, this shift in authorship has not reduced the competitiveness of the award. In fact, these developments actually make the process even more competitive for emerging scholars, as they have increased competition to get published in the first place.

The selection process resulted in a pool of very impressive articles. This is similar to prior years (see Levesque 2011-2018). Unlike prior years, however, there was considerable variation in the range of topics that emerged. Three manuscripts focused on peer relationships (Heinze et al. 2018; Kim et al. 2018; Yun and Graham 2018); two focused on academic achievement (Paschall et al. 2018; Agger et al. 2018); one focused on parenting (Missotten et al. 2018), another on substance use (Debnam et al. 2018), while others focused on risk taking (Duell et al. 2018), on mindfulness (Moreira et al. 2018), psychopathy (Fisher and Brown 2018) and on offending (Wolff et al. 
2018). Notably, Wolff and his colleagues were finalists last year (Wolff et al. 2017; Levesque 2018).

On behalf of the journal's editorial board, I would like to congratulate Dr. Adam A. Rogers and his colleagues. Their recognition comes at a remarkable time in the growth of our journal and fieldand highlight the need to consider and take seriously the intricacies of adolescents' personal relationships.

\section{Compliance with Ethical Standards}

Conflict of Interest The author is the editor of the Journal of Youth and Adolescence.

Publisher's note Springer Nature remains neutral with regard to jurisdictional claims in published maps and institutional affiliations.

\section{References}

Agger, C., Meece, J., \& Byun, S. Y. (2018). The influences of family and place on rural adolescents' educational aspirations and postsecondary enrollment. Journal of Youth and Adolescence, 47(12), 2554-2568.

Debnam, K. J., Milam, A. J., Mullen, M. M., Lacey, K., \& Bradshaw, C. P. (2018). The moderating role of spirituality in the association between stress and substance use among adolescents: differences by gender. Journal of Youth and Adolescence, 47(4), 818-828.

Duell, N., Steinberg, L., Icenogle, G., Chein, J., Chaudhary, N., \& Di Giunta, L., et al. (2018). Age patterns in risk taking across the world. Journal of Youth and Adolescence, 47(5), 1052-1072.

Fisher, J. H., \& Brown, J. (2018). A prospective, longitudinal examination of the influence of childhood home and school contexts on psychopathic characteristics in adolescence. Journal of Youth and Adolescence, 47(10), 2041-2059.

Heinze, J. E., Cook, S. H., Wood, E. P., Dumadag, A. C., \& Zimmerman, M. A. (2018). Friendship attachment style moderates the effect of adolescent exposure to violence on emerging adult depression and anxiety trajectories. Journal of Youth and Adolescence, 47(1), 177-193.

Kim, S., Colwell, S. R., Kata, A., Boyle, M. H., \& Georgiades, K. (2018). Cyberbullying victimization and adolescent mental health: evidence of differential effects by sex and mental health problem type. Journal of Youth and Adolescence, 47(3), 661-672.

Levesque, R. J. R. (2011). Emerging scholar best article award, 2011. Journal of Youth and Adolescence, 40, 1565-1567.
Levesque, R. J. R. (2012). Emerging scholar best article award, 2012. Journal of Youth and Adolescence, 41, 1557-1559.

Levesque, R. J. R. (2013). Emerging scholar best article award, 2013. Journal of Youth and Adolescence, 42, 1910-1912.

Levesque, R. J. R. (2014). Emerging scholar best article award, 2014. Journal of Youth and Adolescence, 43, 2091-2092.

Levesque, R. J. R. (2015). Emerging scholar best article award, 2015. Journal of Youth and Adolescence, 44, 2395-2396.

Levesque, R. J. R. (2016). Emerging scholar best article award, 2016. Journal of Youth and Adolescence, 45, 2497-2498.

Levesque, R. J. R. (2017). Emerging scholar best article award, 2017. Journal of Youth and Adolescence, 46, 2500-2501.

Levesque, R. J. R. (2018). Emerging scholar best article award, 2018. Journal of Youth and Adolescence, 47, 2637-2638.

Missotten, L. C., Luyckx, K., Branje, S., \& Van Petegem, S. (2018). Adolescents' conflict management styles with mothers: longitudinal associations with parenting and reactance. Journal of Youth and Adolescence, 47(2), 260-274.

Moreira, H., Gouveia, M. J., \& Canavarro, M. C. (2018). Is mindful parenting associated with adolescents' well-being in early and middle/late adolescence? The mediating role of adolescents' attachment representations, self-compassion and mindfulness. Journal of Youth and Adolescence, 47(8), 1771-1788.

Paschall, K. W., Gershoff, E. T., \& Kuhfeld, M. (2018). A two decade examination of historical race/ethnicity disparities in academic achievement by poverty status. Journal of Youth and Adolescence, 47(6), 1164-1177.

Rogers, A. A., Ha, T., Updegraff, K. A., \& Iida, M. (2018). Adolescents' daily romantic experiences and negative mood: a dyadic, intensive longitudinal study. Journal of Youth and Adolescence, 47(7), 1517-1530.

Wolff, K. T., Cuevas, C., Intravia, J., Baglivio, M. T., \& Epps, N. (2018). The effects of neighborhood context on exposure to adverse childhood experiences (ACE) among adolescents involved in the juvenile justice system: latent classes and contextual effects. Journal of Youth and Adolescence, 47(11), 2279-2300.

Wolff, K. T., Baglivio, M. T., Intravia, J., Greenwald, M. A., \& Epps, N. (2017). The mobility of youth in the justice system: implications for recidivism. Journal of Youth and Adolescence, 46, 1371-1393.

Yun, H., \& Graham, S. (2018). Defending victims of bullying in early adolescence: a multilevel analysis. Journal of Youth and Adolescence, 47(9), 1926-1937.

Roger J. R. Levesque is Professor of Criminal Justice and (Affiliate) Law, Indiana University. He serves as Editor-in-Chief of the Journal of Youth and Adolescence and the Adolescent Research Review. 